\title{
JM
}

Volume 6 No. 1 (April 2018)

(C) The Author(s)

\section{GAMBARAN PERSEPSI MASYARAKAT TERHADAP PERAN DAN MOTIVASI BIDAN UNTUK MENURUNKAN ANGKA KESAKITAN DBD DI DESA SIAGA MORGO MULYO TAHUN 2017}

\author{
THE PERCEPTION OF SOCIETY TO THE ROLE AND MOTIVATION OF \\ MIDWIVES TO REDUCE THE DANGERABILITY RATE OF DENGUE FEVER IN \\ SIAGA MARGO MULYO VILLAGE IN 2017
}

\author{
RINA \\ DOSEN PRODI DIPLOMA III KEBIDANAN FIKES UNIVED BENGKULU \\ Email : midwife_rina@ymail.com
}

\begin{abstract}
ABSTRAK
Tingginya angka kesakitan dan kematian akibat penyakit demam berdarah merupakan satu penyakit menular yang upaya penurunan kasusnya terkait dengan komitmen nasional dan sering muncul sebagai Kejadian Luar Biasa, hal ini dilihat dari tingginya kasus DBD di Indonesia sebanyak 8.487 orang penderita DBD dengan jumlah kematian 108 orang dan di Provinsi Bengkulu kasus (DBD) ditemui sebanyak 925 kasus, dan meninggal 19 orang, sehingga peran bidan sebagai ujung tombak di masyarakat sangat diperlukan. Penelitian ini betujuan untuk mengetahui gambaran Persepsi masyarakat terhadap Peran dan Motivasi Bidan untuk Menurunkan Angka Kesakitan DBD Di Desa Siaga Morgo Mulyo Tahun 2017.Penelitian ini merupakan penelitian deskriptif, populasi dalam penelitian ini seluruh keluarga yang berada di Desa Siaga Morgo Mulyo Tahun 2017 yang berjumlah 320 kepala keluarga dan sampel diambil 39 orang dengan teknik pengambilan sampel purposive sampling, dengan keriteria inklusi sampel yaitu keluarga yang bersedia menjadi responden, keluarga yang berada di Desa Siaga Morgo Mulyo dan keluarga yang bisa baca tulis.Hasil penelitian ini menunjukan bahwa persepsi masyarakat terhadap peran dan motivasi bidan untuk Menurunkan Angka Kesakitan DBD Di Desa Siaga Morgo Mulyo Tahun 2017 hampir sebagian besar responden (62,5\%) memiliki persepsi yang kurang terhadap peran bidan dan hampir sebagian besar responden $(51,3 \%)$ memiliki persepsi yang kurang terhadap motivasi bidan untuk Menurunkan Angka Kesakitan DBD Di Desa Siaga Morgo Mulyo Tahun 2017.Diharapkan kepada tenaga medis khususnya bidan dapat menekankan dengan melakukan perannya dan motivasi sebagai bidan dalam menurunkan angka kesakitan DBD
\end{abstract}

Kata Kunci : Persepsi, Peran dan Motivasi Bidan

\begin{abstract}
The high rate of morbidity and death from dengue fever is an infectious disease whose efforts to reduce the case related to national commitment and often appear as extraordinary events, this is seen from the high number of dengue cases in Indonesia as many as 8,487 people with Dengue Fever with the number of deaths 108 people and Bengkulu Province case encountered as many as 925 cases, and died 19 people, so the role of midwife as the spearhead in society is needed. This research aimed to find out the perception of society to the Role and Motivation of Midwife
\end{abstract}


to Reduce the Figures of Dengue Fever in Siaga Morgo Mulyo village in 2017.This research is a descriptive research, the population were all families in Siaga Morgo Mulyo village in 2017 totaled 320 heads of family and the sample taken 39 people with purposive sampling sampling technique, with inclusion criterion sample which were those who were willing to become respondents and had an ability in read and writing. The results of this study indicated that people's perception on the role and motivation of midwives to reduce Dengue Fever morbidity in Siaga Morgo Mulyo village in 2017, most of the respondents $(62.5 \%)$ had less perception on the role of midwives and almost all respondents $(51.3 \%)$ had less perception on midwife's motivation to Reduce Dengue Fever Mortality Rate In Siaga Morgo Mulyo village in 2017.It is expected that medics especially midwives can emphasize by performing their role and motivation as midwife in reducing Dengue Fever morbidity.

Keywords: Perception, Roles and Motivation of Midwife

\section{PENDAHULUAN}

Menurut data Badan Kesehatan Dunia (WHO), Asia Pasifik menanggung 75 persen dari beban dengue di dunia antara tahun 2004 dan 2010, sementara Indonesia dilaporkan sebagai negara ke-2 dengan kasus DBD terbesar diantara 30 negara wilayah endemis (Agniya, 2015).

Kementerian Kesehatan RI mencatat jumlah penderita DBD di Indonesia pada bulan Januari-Februari 2016 sebanyak 8.487 orang penderita DBD dengan jumlah kematian 108 orang. Golongan terbanyak yang mengalami DBD di Indonesia pada usia 5-14 tahun mencapai $43,44 \%$ dan usia $15-44$ tahun mencapai 33,25\%. Masyarakat diminta untuk tetap waspada terhadap penyakit DBD mengingat setiap tahun kejadian penyakit demam berdarah dengue di Indonesia cenderung meningkat pada pertengahan musim penghujan sekitar Januari, dan cenderung turun pada Februari hingga ke penghujung tahun (Kemenkes RI, 2016).

Penyakit Demam Berdarah Dengue (DBD) salah satu penyakit menular yang upaya penurunan kasusnya terkait dengan komitmen nasional dan sering muncul sebagai KLB dengan angka kesakitan dan kematian yang relatif tinggi. Di Provinsi Bengkulu Tahun 2015 kasus (DBD) ditemui sebanyak 925 kasus, dan meninggal 19 orang terdiri dari laki-laki sebanyak 12 dan perempuan 7 orang. Kasus terbanyak terjadi di Kota Bengkulu 369 kasus, meninggal 5 orang. Sedangkan di Kabupaten Benteng terdapat
44\% kesakitan akibat DBD (Profil Dinkes Provinsi Bengkulu, 2016).

Berdasarkan data dari Puskesmas Bentiring Bengkulu Tengah Tahun 2016 Angka Kesakitan DBD pada Laki-laki $(47,21 \%)$ dan Perempuan (47,21\%). Angka Kematian akibat penyakit DBD yaitu pada perempuan $(50,0 \%)$. Survey awal yang dilakukan di desa Murgo Mulyo pada tanggal 16 Maret 2017 jumlah Kepala Keluarga yaitu 320 orang dengan jumlah jiwa 1.196 orang yang terdiri dari 572 laki-laki dan 624 perempuan, terdapat 1 orang yang menderita penyakit DBD dan 1 orang bidan yaitu bidan Else, Amd.Keb, sehingga diperlukan peran dan motivasi bidan dalam mencegah dan menanganai kasus DBD.

Desa siaga adalah desa yang penduduknya memiliki kesiapan sumber daya dan kemampuan serta kemauan untuk mencegah dan mnegatasi masalah-masalah kesehatan, bencana dan kegawatdaruratan tugas kesehatan secara mandiri. Pada awalnya istilah siaga digunakan hanya untuk program Kesehatan Ibu dan Anak dengan singkatan siap antar jaga dalam upaya penurunan angka kematian ibu dan bayi di pedesaan. Tujuan Desa Siaga secara umum yaitu terwujudnya masyarakat desa yang sehat, serta peduli dan tanggap terhadap permasalahan kesehatan di wilayahnya (Pramudho, 2009)

Persepsi masyarakat terhadap peran dan motivasi bidan ialah pengamatan seseorang yang berasal dari pengamatan langsung dari proses belajar atau sosialisasi mengenai halhal yang dilakukan bidan (Rakhmad, 2008). 
Peran dan motivasi bidan di tingkat kecamatan untuk melakukan survei dan sosialisasi pencegahan terhadap kasus DBD (Aditama, 2011). Menurut (Estiwidani, dkk. 2008) peran dan fungsi bidan dalam pelayanan kebidanan adalah sebagai pelaksana, pengelola, pendidik, dan peneliti. Sedemikian kompleksnya peran, fungsi, dan tanggung jawab seorang bidan dalam melaksanakan tugasnya memberikan pelayanan kebidanan yang terbaik dan professional kepada masyarakat maka untuk keberhasilan dalam mencapai tujuan tersebut diperlukan landasan yang kuat berupa kompetensi bidan, sehingga meningkatkan persepsi yang baik terhadap bidan.

DHF (Dengue Haemorragic Fever) merupakan penyakit demam akut yang disebabkan oleh empat serotipe virus dengue dan ditandai dengan gejala klinis utama yaitu demam tinggi, manifestasi perdarahan, hepatomegali dan tanda kegagalan sirkulasi sampai timbul rejatan (sindrom renjatan dengue) sebagai akibat dari kebocoran plasma yang dapat menyebabkan kematian (Padila, 2013).

Menurut (Notoatmodjo, 2010) motivasi adalah keinginan yang terdapat pada diri seseorang individu yang mendorongnya untuk melakukan perbuatan-perbuatan, tindakan, tingkah laku, atau perilaku. Bidan juga dapat memberikan promosi kesehatan dan memberikan motivasi dalam melakukan PHBS (Prilaku Hidup Bersih dan Sehat) dalam pencegahan berkembangnya nyamuk Aedes Albopictus dan Aedes Aegepty.

Berdasarkan latar belakang inilah maka peneliti tertarik untuk melakukan penelitian "Gambaran Persepsi Masyarakat tehadap Peran dan Motivasi Bidan untuk Menurunkan Angka Kesakitan DBD Di Desa Siaga Morgo Mulyo Tahun 2017’.

\section{TUJUAN PENELITIAN}

Mengetahui Gambaran Persepsi masyarakat terhadap Peran dan Motivasi Bidan untuk Menurunkan Angka Kesakitan DBD Di Desa Siaga Morgo Mulyo Tahun
2017.

\section{METODE PENELITIAN}

Desain penelitian ini merupakan penelitian deskriptif untuk melihat gambaran persepsi masyarakat terhadap peran dan motivasi bidan untuk menurunkan angka kesakitan DBD Di Desa Siaga Morgo Mulyo Tahun 2017. Populasi dalam penelitian ini adalah seluruh keluarga yang berada di Desa Siaga Morgo Mulyo Tahun 2017 yang berjumlah 320 kepala keluarga. Sampel adalah sebagian besar keseluruhan objek yang diteliti dan dianggap mewakili populasi (Notoatmodjo, 2010). Besar sampel dalam penelitian ini yaitu sebanyak 39 orang dengan teknik pengambilan sampel purposive sampling yaitu pengambilan sampel berdasarkan pertimbangan tertentu.

\section{HASIL PENELITIAN}

Tabel 1. Distribusi Frekuensi gambaran persepsi masyarakat terhadap peran bidan untuk Menurunkan Angka Kesakitan DBD Di Desa Siaga Morgo Mulyo Tahun 2017

\begin{tabular}{ccc}
\hline Peran Bidan & Frekuensi & Persentase (\%) \\
\hline Kurang & 24 & 61.5 \\
\hline Baik & 15 & 38.5 \\
\hline Total & 39 & 100.0 \\
\hline
\end{tabular}

Berdasarkan tabel 1 di atas diketahui hampir sebagian besar responden $(62,5 \%)$ memiliki persepsi yang kurang terhadap peran bidan untuk Menurunkan Angka Kesakitan DBD Di Desa Siaga Morgo Mulyo Tahun 2017.

Tabel 2. Distribusi Frekuensi gambaran persepsi masyarakat terhadap motivasi bidan untuk Menurunkan Angka Kesakitan DBD Di Desa Siaga Morgo Mulyo Tahun 2017 


\begin{tabular}{ccc}
\hline Sikap & Frekuensi & Persentase (\%) \\
\hline Kurang & 20 & 51.3 \\
\hline Baik & 19 & 48.7 \\
\hline Total & 39 & 100.0 \\
\hline
\end{tabular}

Berdasarkan tabel 2 di atas diketahui hampir sebagian besar responden $(51,3 \%)$ memiliki persepsi yang kurang terhadap motivasi bidan untuk Menurunkan Angka Kesakitan DBD Di Desa Siaga Morgo Mulyo Tahun 2017.

Tabel 3. Distribusi Frekuensi gambaran Angka Kejadian DBD Di Desa Siaga Morgo Mulyo Tahun 2017

\begin{tabular}{ccc}
\hline Angka Kejadian DBD & Frekuensi & Persentase (\%) \\
\hline Kejadian DBD & 2 & $0,16 \%$ \\
\hline Jumlah Jiwa & 1196 & 100 \\
\hline
\end{tabular}

Berdasarkan tabel 3 di atas diketahui bahwa kejadian DBD Di Desa Murgo Mulyo Tahun 2017 yaitu sebagian kecil $(0,16 \%)$

\section{PEMBAHASAN}

\section{a. Gambaran Persepi masyarakat terhadap peran bidan untuk Menurunkan Angka Kesakitan DBD Di Desa Siaga Morgo Mulyo Tahun 2017}

Hasil penelitian ini diketahui bahwa hampir setengah responden $(38,5 \%)$ memiliki persepsi yang baik karena responden merasa peran bidan sudah baik dalam melakukan tuasnya dan hampir sebagian besar responden $(61,5 \%)$ memilki persepsi yang kurang terhadap peran bidan karena responden mengatakan bahwa tidak berpartisipasi dalam mengajak masyarakat misalnya menjaga lingkungan, menyiapkan alat, responden mengatakan bidan hanya pernah melakukan penyuluhan itu pun waktu mereka berobat, responden juga menatakan bidan juga tidak dekat dengan masyarakat.

Menurut Rakhmad (2008), menyatakan persepsi adalah pengalaman tentang objek, peristiwa atau hubungan-hubungan yang diperoleh dengan menyimpulkan informasi dan menafsirkan pesan. Persepsi ialah memberikan makna pada stimulasi inderawi (sensory stimuli).

Menurut (Estiwidani, dkk. 2008) peran dan fungsi bidan dalam pelayanan kebidanan adalah sebagai pelaksana, pengelola, pendidik, dan peneliti. Sedemikian kompleksnya peran, fungsi, dan tanggung jawab seorang bidan dalam melaksanakan tugasnya memberikan pelayanan kebidanan yang terbaik dan professional kepada masyarakat maka untuk keberhasilan dalam mencapai tujuan tersebut diperlukan landasan yang kuat berupa kompetensi bidan, sehingga meningkatkan persepsi yang baik terhadap bidan.

Peran bidan sebagai pelaksana yaitu bidan mempunyai tiga kategori tugas mandiri, tugas kolaborasi/kerjasama, tugas ketergantungan/merujuk. Peran bidan sebagai Pengelola yaitu mengembangkan pelayanan dasar kesehatan terutama pelayanan kebidanan, bersama tim kesehatan dan pemuka masyarakat mengkaji kebutuhan terutama yang berhubungan dengan kesehatan ibu dan anak untuk meningkatkan dan mengembangkan program pelayanan kesehatan di wilayah kerjanya, menyusun rencana kerja sesuai dengan hasil pengkajian dengan masyarakat, mengelola kegiatan kegiatan pelayanan kesehatan masyarakat. Peran bidan sebagai pendidik yaitu memberikan pendidikan pendidikan dan penyuluhan, penyuluhan kesehatan kepada individu keluarga kelompok dan masyarakat tentang penanggulangan masalah kesehatan, bersama klien pengkajian kebutuhan akan pendidikan dan penyuluhan kesehatan masyarakat, bersama klien pihak terkait menyusun rencana penyuluhan kesehatan masyarakat, menyiapkan alat dan bahan pendidikan dan penyuluhan sesuai dengan rencana yang telah disusun, bersama klien mengevaluasikan hasil pendidikan atau penyuluhan kesehatan masyarakat dan menggunakannya untuk memperbaiki dan meningkatkan program di masa yang akan dating. Peran sebagai peneliti/investigator yaitu mengidentifikasi kebutuhan investigasi 
yang akan dilakukan, menyusun rencana kerja pelatihan, melaksanakan investigasi sesuai dengan rencana, mengolah data menginterprestasikan data hasil investigator dan menyusun laporan hasil investigasi dan tindak lanjut, memanfaatkan hasil investigasi untuk meningkatkan dan mengembangkan program kerja atau pelayanan kesehatan (Estiwardani, 2008).

Hasil penelitian ini sejalan dengan penelitian Purwatiningsih (2010) dengan judul Persepsi Masyarakat terhadap Peran Tenaga Kesehatan dalam Menurunkan Kesakitan DBD di Kelurahan Krajan Kabupaten Klaten yaitu mayoritas responden menganggap peran bidan kurang terhadap penurunan kesakitan DBD.

\section{b. Gambaran Persepi masyarakat terhadap peran bidan untuk Menurunkan Angka Kesakitan DBD Di Desa Siaga Morgo Mulyo Tahun 2017}

Hasil penelitian ini diketahui bahwa hampir sebagian besar responden $(51,3 \%)$ memiliki persepsi yang kurang disebabkan sama halnya dengan kurangnya peran bidan motivasi pun kurang yang diberikan bidan, selain itu masyarakat mengatakan jarang bertemu dengan bidan karena alasan kekebun atau bekerja, jika sakit pun biasanya masyarakat berobat ke bidan yang berada di luar Desa Siaga Murgo Mulyo dan hampir setengah responden $(48,7 \%)$ memiliki persepsi baik terhadap motivasi bidan karena masyarakat berada didekat rumah bidan sehingga sering bertamu dan bertanya tentang masalah kesehatan untuk Menurunkan Angka Kesakitan DBD Di Desa Siaga Morgo Mulyo Tahun 2017. Motivasi bidan di tingkat kecamatan untuk melakukan survei dan sosialisasi pencegahan terhadap kasus DBD (Aditama, 2011).

Motif atau motivasi berasal dari bahasa Latin "movere" yang berarti dorongan dalam diri manusia untuk bertindak atau berperilaku. Motivasi adalah keinginan yang terdapat pada diri seseorang individu yang mendorongnya untuk melakukan perbuatan-perbuatan, tindakan, tingkah laku, atau perilaku (Notoatmodjo, 2010).

Sejalan dengan penelitian yang dilakukan oleh Impartina (2012) dengan judul Hubungan Motivasi Perilaku Bidan dalam Pencegahan Penyakit DHF di Desa Karangcangkring Kedungpring Lamongan yaitu $46 \%$ memiliki motivasi rendah.

\section{c. Gambaran Angka Kejadian DBD Di Desa Murgo Mulyo Tahun 2017}

Berdasarkan hasil penelitian diketahui bahwa angka kejadian DBD Di Desa Murgo Mulyo Tahun 2017 yaitu sebagian kecil $(0,16 \%)$. Hal ini menunjukan masih terdapat kejadian DBD, akan tetapi angka kejadian DBD Di desa murgo Mulyo lebih rendah dibandingkan dengan angka kejadian DBD di Kabupaten Benteng terdapat 44\% kesakitan akibat DBD pada tahun 2016 (Profil Dinkes Provinsi Bengkulu, 2016).

Berdasarkan data dari Puskesmas Bentiring Bengkulu Tengah Tahun 2016 Angka Kesakitan DBD pada Laki-laki $(47,21 \%)$ dan Perempuan (47,21\%). Angka Kematian akibat penyakit DBD yaitu pada perempuan (50,0\%). Menurut (Padila, 2013) demam Berdarah atau DHF (Dengue Haemorragic Fever) adalah penyakit demam akut yang disebabkan oleh empat serotipe virus dengue dan ditandai dengan gejala klinis utama yaitu demam tinggi, manifestasi perdarahan, hepatomegali dan tanda kegagalan sirkulasi sampai timbul rejatan (sindrom renjatan dengue) sebagai akibat dari kebocoran plasma yang dapat menyebabkan kematian. DHF (Dengue Haemorragic Fever) adalah merupakan penyakit anak yang disebabkan oleh virus dengue yang termasuk golongan arbovirus melalui gigitan nyamuk Aedes aegypti betina.

\section{KESIMPULAN}

Berdasarkan pembahasan hasil penelitian tentang gambaran persepsi masyarakat terhadap peran dan motivasi bidan untuk Menurunkan Angka Kesakitan 
DBD Di Desa Siaga Morgo Mulyo Tahun 2017, maka dapat ditarik kesimpulan bahwa:

a. Hampir sebagian besar responden $(62,5 \%)$ memiliki persepsi yang kurang terhadap peran bidan untuk Menurunkan Angka Kesakitan DBD Di Desa Siaga Morgo Mulyo Tahun 2017.

b. Hampir sebagian besar responden $(51,3 \%)$ memiliki persepsi yang kurang terhadap motivasi bidan untuk Menurunkan Angka Kesakitan DBD Di Desa Siaga Morgo Mulyo Tahun 2017.

c. Sebagian kecil $(0,16 \%)$ angka kejadian DBD Di Desa Murgo Mulyo Tahun 2017.

\section{SARAN}

Berdasarkan hasil penelitian dan pembahasan peneliti akan memberikan saran kepada beberapa pihak yang terkait antara lain kepada :

\section{Saran Akademis}

Hasil penelitian ini diharapkan dapat menjadi referensi dalam pengembangan ilmu pengetahuan terutama dalam ruang lingkup kesehatan mengenai kesakitan DBD, khususnya yang berkaitan dengan persepi masyarakat terhadap peran bidan untuk Menurunkan Angka Kesakitan DBD.

2. Saran Praktis

\section{a. Bagi Institusi Pendidikan}

Diharapkan dapat dijadikan sebagai salah satu sarana memperkaya ilmu pengetahuan dan dapat dijadikan sebagai bahan referensi atau literatur serta pembelajaran saat melakukan praktek klinik kebidanan.

\section{b. Bagi Tempat Penelitian}

Diharapkan kepada tenaga medis khususnya bidan dapat menekankan dengan melakukan perannya dan motivasi sebagai bidan dalam menurunkan angka kesakitan DBD. c. Bagi Penelitian Selanjutnya

Diharapkan penelitian ini dapat menjadi tambahan referensi dalam penelitian selanjutnya selanjutnya dengan menggunakan hubungan antara variabel dan waktu yang berbeda.

\section{DAFTAR PUSTAKA}

Aditama. (2011). Modul Pelatihan Penanganan Demam Berdarah.Jakarta: Kemenkes RI

Agniya. (2015). Laporan KLB Demam Berdarah Di Dunia. Di akses (tanggal 12 Maret 2017) diunduh dari http://www.cnnindonesia.com

Amin \& Hardhi. (2016). Asuhan Keperawatan Praktis Jilid 1. Yogyakarta: Mediaaction Publishing

Dinas Kesehatan Provinsi Bengkulu. (2016). Profil Kesehatan Propinsi Bengkulu Tahun 2015. Bengkulu: Dinkes Kota Bengkulu

Dinas Kesehatan Kabupaten Benteng. (2016) Estiwidana, dkk. (2011). Konsep Kebidanan. Yogyakarta: Fitramaya

Impartina. (2012). Hubungan Motivasi Perilaku Bidan dalam Pencegahan Penyakit DHF di Desa Karangcangkring Kedungpring Lamongan. Di akses (tanggal 04 Agustus 2017) diunduh dari http://stikesmuhla.ac.id

Kemenkes RI. (2016). Wilayah KLB ada Di 11 Provinsi. Di akses (tanggal 12 Maret 2017) diunduh dari http://www.depkes.go.id/

Maryunani, A. (2016). Manajemen Kebidanan Terlengkap. Jakarta Timur: CV. Trans Info Media

Nanda. (2015). Aplikasi Asuhan Keperawatan Berdasarkan Diagnosa Medis dan NANDA. Yogyakarta: Mediaaction Publishing

Notoadmojo. 2010. Pengetahuan, Teori dan aplikasinya. Jakarta: Selemba merdeka

Notoatmodjo. 2010. Metodologi Penelitian Kesehatan. Jakarta: Selemba merdeka

Padila. 2013. Asuhan Keperawatan Penyakit 
Dalam. Yogyakarta; Nuha Medika

Pramudho. (2009). Upaya Pemberdayaan Masyarakat di Bidang Kesehatan Melalui Peran Bidan di Desa. Di akses (tanggal 06 Juni 2017) diunduh dari http://journal.unair.ac.id/downloadfull.

Purwatiningsih (2010). Persepsi Masyarakat terhadap Peran Tenaga Kesehatan dalam Menurunkan Kesakitan DBD di Kelurahan Krajan Kabupaten Klaten. Di akses (tanggal 04 Agustus 2017) diunduh dari https://eprints.uns.ac.id

Rakhmad. (2008). Psikologi Komunikasi. Bandung: PT. Remaja Rosdakarya

Sardiman. (2011). Interaksi dan Belajar Mengajar. Di akses (tanggal 12 Maret 2017) diunduh dari http://repository.upi.edu/

Siregar \& Hartini (2010). Teori Belajar dan Pembelajaran. Di akses (tanggal 12 Maret 2017) diunduh dari http://repository.upi. Bibliography.pdf

Soekanto. (2009).Peranan Sosiologi Suatu Pengantar Edisi Baru. Jakarta: Pustka Pers

Sulistyaningsih. (2012). Metode Penelitian Kebidanan Cetakan ke-2. Yogyakarta: Graha Ilmu

Wawan. (2010). Pengetahuan, Sikap dan Prilaku Manusia. Yogyakarta: Nuha Medika 